\title{
Dynamics in the Origins of Technological Knowledge in Early Firm Years: Implications for New Product Introductions
}

DOI:

10.1287/stsc.2019.0089

\section{Document Version}

Accepted author manuscript

Link to publication record in Manchester Research Explorer

Citation for published version (APA):

Hashai, N., \& Zander, I. (2019). Dynamics in the Origins of Technological Knowledge in Early Firm Years: Implications for New Product Introductions. Strategy Science, 4(3), 217-233.

https://doi.org/10.1287/stsc.2019.0089

\section{Published in:}

Strategy Science

\section{Citing this paper}

Please note that where the full-text provided on Manchester Research Explorer is the Author Accepted Manuscript or Proof version this may differ from the final Published version. If citing, it is advised that you check and use the publisher's definitive version.

\section{General rights}

Copyright and moral rights for the publications made accessible in the Research Explorer are retained by the authors and/or other copyright owners and it is a condition of accessing publications that users recognise and abide by the legal requirements associated with these rights.

\section{Takedown policy}

If you believe that this document breaches copyright please refer to the University of Manchester's Takedown Procedures [http://man.ac.uk/04Y6Bo] or contact uml.scholarlycommunications@manchester.ac.uk providing relevant details, so we can investigate your claim.

\section{OPEN ACCESS}




\title{
DYNAMICS IN THE ORIGINS OF TECHNOLOGICAL KNOWLEDGE IN EARLY
} FIRM YEARS - IMPLICATIONS FOR NEW PRODUCT INTRODUCTIONS

\author{
Niron Hashai \\ Arison School of Business \\ The Interdicplinary Center \\ Herzliya, Israel \\ e-mail: nhashai@idc.ac.il \\ Ivo Zander \\ Department of Business Studies \\ Uppsala University \\ Uppsala, Sweden \\ e-mail: Ivo.Zander@ fek.uu.se
}

Forthcoming at Strategy Science 


\begin{abstract}
We document how, in the early years of high technology firms, the origination of technological knowledge starts with firm founders, then shifts to other firm members, and later on to external stakeholders. We further show that greater reliance on founder technological knowledge is initially positively but later on negatively associated with new product introductions, whereas the opposite relationship holds for reliance on firm member and external stakeholder technological knowledge. By assessing the dynamics and effects of technological knowledge origins on new product introductions, involving founders, firm members and external stakeholders, the paper offers new empirical and theoretical insights pertaining to the role of technological knowledge in high technology firm growth.
\end{abstract}




\section{INTRODUCTION}

Technological knowledge ${ }^{1}$ is the engine of technological progress and economic growth. It is the primary source of new products and services, such as incandescent lighting, personal computers, or mobile telephony, which have transformed and enhanced the life of billions of people. Technological knowledge is also the foundation of new high technology ventures that aspire to break new ground with their product offerings, and it continues to be at the core of product development and renewal of already established high technology firms.

But where does the technological knowledge of newly established high technology firms come from, and how is it connected to new product introductions? These questions have been explored in several streams of research. The first stream of research emphasizes firm founders as the primary knowledge source of high technology firms and as key determinants of their productive output (Baron, Burton and Hannan, 1996; Burton, 2001; Fauchart and Gruber, 2011). This stream of research contends that the knowledge and experiences of founders play a decisive role in recognizing market opportunities and translating technological advancements into new products (Shane, 2000; Wasserman, 2003; Dencker, Gruber and Shah, 2009; Fern, Cardinal and O’Neill, 2012; Dencker and Gruber, 2015). Another research stream argues that firm members and the technological knowledge embedded within firm social relationships (Kogut and Zander, 1992; Grant, 1996) are an important source of knowledge and driver of high technology firms' new product introductions. This knowledgebased view stresses the supporting roles of common organizational identities and shared cognitive frames among firm members for the conversion of technological knowledge into new products (Kogut and Zander, 1996; Brown and Duguid, 2001; Håkanson, 2007). The fundamental idea is that firm members can make use of extensive and privileged technological knowledge exchange with other firm members working on similar problems, which reduces the cost and time of new product introductions (Kogut and Zander, 1992; Galunic and Rodan, 1998; Smith, Collins and Clark, 2005).

\footnotetext{
${ }^{1}$ In the context of the current paper, technological knowledge refers to knowledge that concerns the creation and use of technical means, specifically with new products and services developed and commercialized by business firms.
} 
A third stream of research instead emphasizes how firms draw upon the technological knowledge produced by their external stakeholders, such as customers, suppliers and partners. Von Hippel (1976, 1988) and Zander and Zander (2005) show how either suppliers or customers play a central role as sources of new technological knowledge that becomes part of firms' products. Other work has highlighted how knowledge originating in alliances and network ties (Mowery, Oxley and Silverman, 1996; Kale, Singh and Perlmutter, 2000; Yli-Renko, Autio and Sapienza, 2001) plays an important role in high technology firms' innovative activities and productive output (Ahuja, 2000; Stuart, 2000; Sampson, 2007; Phelps, 2010). An important feature of external sources of technological knowledge is that they facilitate the acquisition of technological knowledge that is complementary to that of the firm, thereby leading to enhanced technological innovation and the introduction of novel products (Cassiman and Veugelers, 2006; Chesbrough, 2003).

These streams of research have significantly enhanced our understanding of the sources of technological knowledge in high technology firms and how they are connected to new product introductions. Yet, when it comes to the technological knowledge sources of newly established high technology firms ${ }^{2}$, as of their inception and over their first defining and formative stages of development (Kazanjian, 1988), we are still largely in the dark with regard to understanding whether founders, firm members or external stakeholders play a more decisive role in driving the creation of new technological knowledge and in facilitating a significant activity in which newly established high technology firms engage - the introduction of new products (Hashai, 2015). Lacking this understanding means that central and managerially important aspects of the formation of technological knowledge in high technology new firms and their propensity to introduce new products have gone unnoticed and unexplained.

In this paper, we aim to address this empirical void by unpacking the temporal trends in the reliance of newly established high technology firms on different sources of technological knowledge, and studying the consequences of such temporal trends for new product introductions. Specifically,

\footnotetext{
${ }^{2}$ More specifically, newly established firms that are not spinoffs from existing firms, management buy-outs or joint ventures of existing firms.
} 
our research questions are: (1) How do the sources of newly established high technology firms' technological knowledge shift over time, as of inception and throughout their early development? and (2) to what extent do shifts in the reliance on different sources of technological knowledge influence the introduction of new products in these firms?

Studying a unique dataset documenting the sources of technological knowledge (in terms of patent citations) and new product introductions of a sample of 153 Israel-based, high technology firms, we explore how newly established high technology firms change their reliance upon the technological knowledge of their founders, firm members other than founders, and external stakeholders (specifically suppliers, alliance partners and customers). We find distinctive systematic trends in the propensity of our sample firms to rely on these three sources of technological knowledge. Initially, the technological knowledge of newly established high technology firms, to an increasing extent, originates in the founders of these firms. However, as the firms develop, their reliance on technological knowledge originating from other firm members also increases, while the knowledge originating in founders starts to decline. Yet, we further show that the reliance on technological knowledge originating from external stakeholders increases monotonically, and about a decade after firm inception equals to the reliance on technological knowledge originating in both founders and firm members.

In parallel, we find that, initially, founders' contribution to their firms' technological knowledge is positively associated with new product introductions, but that this relationship turns negative as firms develop over time. In contrast, the contributions of firm members and external stakeholders to technological knowledge are initially negatively associated with the introduction of new products, but these relationships turn positive over time. Taken together, these findings suggest that while the technological knowledge of founders is instrumental in charting out the first products of high technology firms, in the longer term sustained dominance of founders, rather than new product initiatives that emerge internally (among other firm members) and externally (among stakeholders), attenuates new product introductions.

We draw upon these findings to outline a theoretical framework that explores the interlinkages between evolving sources of technological knowledge in newly established high technology firms. The framework expounds why the technological knowledge of founders plays a critical role in early 
product developments, and how the gradual shift towards technological knowledge originating from firm members and, later on, external stakeholders matters for continued new product development. In cases where this shift in technological knowledge sources is disrupted, either by too early reliance on firm member and external stakeholder technological knowledge or by continued reliance on founder technological knowledge throughout later stages of firm development, there will be an adverse effect on new product introductions.

The study makes three main contributions. First, we provide novel empirical evidence that shows how, during the early years after firm inception, the origins of high technology firms' technological knowledge shift across founders, other firm members, and external stakeholders. We further provide novel empirical evidence on how shifts in the contribution of the sources of technological knowledge influence new product introductions. To our knowledge, the paper is the first to systematically connect evolving sources of technological knowledge with the introduction of new products in firms during their early years of development.

Second, by documenting temporal cycling between different sources of technological knowledge our findings serve to expound the applicability of different perspectives on technological knowledge and new product introductions. We show that internal sources (founders and firm members are likely to precede external stakeholders in their contribution to firms' technological knowledge, but that with time the contribution of external stakeholders surpasses that of internal sources. Third, the linkages between evolving sources of technological knowledge and new product introductions highlight how an initial emphasis on founder technological knowledge and a later emphasis on non-founder technological knowledge (that of firm members and external stakeholders) facilitates continued new product introductions. Overall, the paper forges a knowledge-based connection between the formative years of high technology firms, during which the founders play a prominent and critical role, and the later stages when such firms approach and enter organizational maturity (Aldrich and Ruef, 2006). This is an issue that so far has remained largely unexplored in the extant literature.

In the sections that follow, we first outline the main views on the sources of technological knowledge and their impact on new product introductions in newly established high technology firms. We then present our data and results with regard to dynamics in the origins of technological 
knowledge in early firm years and the role of such dynamics for new product introductions. The discussion that follows outlines a theoretical framework, rooted in our empirical observations, that explains how newly established high technology firms change their main sources of technological knowledge as they develop. The framework further explains how the degree of reliance on different sources of technological knowledge, at different points of time, impacts the capacity of these firms to introduce new products. The paper concludes with a summary of our main findings and conclusions.

\section{DYNAMICS IN TECHNOLOGICAL KNOWLEDGE ORIGINS AND NEW PRODUCT INTRODUCTIONS}

The extant literature emphasizes the prominence of firm founders as a key source of technological knowledge in newly established high technology firms, building on the observation that new firms and products come about as founding entrepreneurs discover and act upon unique and hitherto unimagined business ideas (Schumpeter, 1934; Kirzner, 1985). During their early development stages these firms remain dependent upon the technological knowledge of their founders (Shane, 2000; Kaplan, Sensoy and Strömberg, 2009), who typically become personally immersed in devising the functions of their firms' first new product. Starting with the founders' idea of a technological frame - what the new product is and what it can do (Kaplan and Tripsas, 2008) - the scope of firm activities expands through founder problem solving that probes and extends the boundaries of the evolving new product (Shan, 1990; Nickerson and Zenger, 2004). As suggested by Kazanjian (1988: 263), in the early stages of new firm development "almost all activity focused on technical issues [are] defined and directed by the founding entrepreneur(s)".

Once the initial technological challenges of introducing the firm's first product have been satisfactorily resolved, founders may also start exploring a number of related technological applications and market opportunities (Helfat and Raubitschek, 2000). The process of branching out into new products remains, to a large extent, dependent upon the extension of the founders' technological knowledge into areas that are close to the original product (Ronstadt, 1988; Stern and Henderson, 2004; Kaplan et al., 2009). 
However, the literature is ambiguous regarding the role that non-founders play in shaping the technological knowledge and product portfolios of newly established high technology firms. Two different perspectives are informative with regard to the dynamics in the technological knowledge sources of such firms, as they develop their knowledge and build their product portfolio. The first perspective contends that because personal involvement can only partially meet the demands of a growing and increasingly complex set of operations, founders will also hire a growing number of firm members for leveraging and complementing their technological knowledge (Almeida and Kogut, 1999). These newly recruited firm members are likely to include a significant proportion of skilled engineers, who will want to use the firm as a platform for their personal and professional development (Saxenian, 1994). A direct implication of a growing number of firm members would be that the contribution of internal non-founder knowledge sources to the technological knowledge of the high technology firm increases. Over time, there will therefore also be a corresponding shift in the origination and pursuit of new product ideas, where greater contributions will likely emerge on the account of the increasing number of firm members whose technological knowledge becomes leveraged in technological and product development activities (Burgelman, 1983; Katila and Ahuja, 2002).

The other perspective suggests how the technological knowledge of high technology new firms is shaped by knowledge residing among external stakeholders, such as partner firms and suppliers (Stuart, 2000; Yli-Renko, et al., 2001; Sampson, 2007), and how these external stakeholders affect the firms' capacity to introduce new products (Mallapragada, Grewal and Lilien, 2012). In a similar vein, customers have been shown to play an important role when it comes to generating and developing ideas for new product introductions (von Hippel, 1976; von Hippel, 1988; Riggs and von Hippel, 1996; Franke and Shah, 2003; Zander and Zander, 2005).

Although broadening the interfaces with external stakeholders may consume significant time and resources (Dyer and Nobeoka, 2000; Almeida, Dokko and Rosenkopf, 2003), interaction with such stakeholders offers access to complementary technological knowledge which essentially originated outside firm boundaries (Ahuja, 2000; Laursen, Leone and Torrisi, 2010), and thus can lead to significant changes in the firm's technological knowledge domain (Mowery et al., 1996; Kale et al., 2000; Cassiman and Veuglers, 2006; Phelps, 2010; Zhou and Li, 2012). Partner firms, suppliers and 
customers may thus grant newly established high technology firms a firsthand understanding of the needs of their external environment, spark novel technological ideas and innovations, and serve as important sources of technological knowledge in early product development processes. As the initially small size and limited human capital resources of new high technology firms places constraints on their ability to rely upon their own technological knowledge, they may increasingly use their partners, as well as their suppliers and customers, as the lead sources of technological knowledge.

Given these different and in part contrasting perspectives on the process through which technological knowledge is formed in newly established high technology, we are interested in documenting the changes in the reliance of newly established high technology firms on three sources of technological knowledge - founders, non-founding firm members and external stakeholders. We are specifically interested in analyzing developments soon after the firms' inception and over their first years of development, in order to distinguish shorter and longer-term trends in the reliance on any of the three sources of technological knowledge.

We are also interested in understanding how the propensity to rely upon each of these sources of technological knowledge influences the ability of newly established high technology firms to introduce new products. If, as extant literatures suggest, technological knowledge is a key driver of new product introductions, changes in the reliance on different sources of knowledge should have observable effects on the capacity of newly established high technology firms to introduce new products. ${ }^{3}$ Is a relatively high degree of reliance on a specific source of technological knowledge during the early days of new high technology firms likely to be positively associated with new product introductions? Does a high degree of reliance on a source of technological knowledge have a different effect on the capacity to introduce new products as high technology firms become more established? These are the empirical issues we turn to next.

\footnotetext{
${ }^{3}$ Clearly, firms in general and newly established high technology firms in particular also rely upon other technological knowledge that is commonly known and disseminated (such as third party patents, or knowledge that is in the public domain). Indeed, in the process of patenting, patent examiners often require firms to add citations to such knowledge. Yet, such commonly known and disseminated technological knowledge is unlikely to vary in its influence on newly established high technology firms, unless it is combined with technological knowledge that specifically relates to the firm through its founders, firm members and external stakeholders. In other words, it is the application of distinctive technological knowledge and the integration of that knowledge with a wider knowledge domain that defines the capability of high technology firms to introduce new products.
} 


\section{DATA}

\section{Sample}

Our dataset includes a sample of Israel-based, high technology firms, traced as of their inception and over their early years of development. Israel is a suitable empirical setting, as it is ranked first in the world in per capita venture capital investments and in per capita high technology startup formations (Bosma and Levie, 2011), and it is world renowned for its high technology entrepreneurial initiatives (Senor and Singer, 2009). As we detail below our sample firms are extensively involved in the use and generation of new technological knowledge.

We used the full list of Israel-based, high technology firms constructed by Dolev and Abramovitz Ltd (D\&A) for the year 2007 as our main source to identify such firms. D\&A is a private company that collects information on the Israeli high technology sector, including information on firms dating back to the mid-1980s. The 2007 D\&A dataset includes 408 firms that have reached the stage where they have started introducing products. Since we are interested in analyzing dynamics in the origins of technological knowledge and the effects of such dynamics on new product introductions over early firm years, we focus on firms that have gone through various stages of seed finance and technological development, reaching the point where they have already developed commercial products.

One hundred and sixty five of the firms in the original dataset (representing 40 percent of the original sample) were randomly selected. For these firms, extensive data collection from secondary sources was conducted. These sources include: The D\&A dataset, the Israel Venture Capital (IVC) dataset, annual financial reports, prospectuses and other written reports, documents supplied by the firms, as well as press announcements from Lexis Nexis Academic. The D\&A and the IVC datasets are both recognized as two comprehensive sources on Israeli high-tech industries and allowed us to gain objective information on the development of the sampled firms, including their financial data. Patent information and patent citation data for the sampled firms were collected from NBER U.S. Patent Citations Data File and the United States Patent and Trademark Office (USPTO) database. Annual data on founders and firm members of the sample firms were collected from multiple sources, including the D\&A and IVC datasets and the Dun \& Bradstreet Israel dataset (DunsGuide Global). We 
further approached the sample firms directly to receive more detailed information on the experience of founders and firm members prior to their involvement with a given firm. The identification of suppliers, partners and customers of the sample firms, on an annual basis, was based on press announcements from Lexis Nexis Academic.

Out of the 165 firms, we screened out 12 firms for which data was incomplete. This resulted in a final sample of 153 firms. T-test comparisons between the 153 sampled firms and the 255 nonsampled firms show no evidence of non-response bias in terms of the averages of firm sales, number of employees, firm age, firm valuation and firm industrial classification (at the six-digit North American Industrial Classification System (NAICS) level).

Data collection resulted in a dataset of 932 firm-year observations for the 153 firms over the period 1990-2006. The sample firms operated in ten core high technology six-digit NAICS industries: printing machinery and equipment, semiconductor machinery, optical instrument and lens, computer terminal, telephone apparatus, radio and television broadcasting and wireless communications equipment, semiconductor and related device, electronic components, electromedical and electrotherapeutic apparatus, and surgical and medical instrument. In all these industries, firms value and widely make use of patents, the citations of which are our main proxy for the sources of technological knowledge that newly established high technology firms draw upon.

\section{Main Variables and Measures}

The variables required for the current study and their measures and sources are presented below and further detailed in Appendix Table 1.

We use three main variables as measures for the technological knowledge sources of newly established high technology firms: number of citations of founder patents, number of citations of firm member patents and number of citations of external stakeholder patents. Since our focus is on technological knowledge we follow the extant literature (e.g. Katila and Ahuja, 2002; Laursen and Salter, 2006) and use backward patent citations as means to identify the sources of technological knowledge that firms draw upon. This approach is supported by the fact that all the firms in our sample have patented. To do that, we take the total number of patents a firm has applied for in a given year, and calculate the number of backward citations in these patents to patents where founders, firm 
members, or individuals owning or employed by external stakeholders are listed as inventors or contributors. Referring to the year of application allows us to get the closest to the time when technological knowledge is created. ${ }^{4}$ Since it is common for Israel-based firms to apply for patents and sell their products in the United States (on average 66 percent of the sample firms' sales are in the United States) we refer to patent applications at the USPTO. This also reduces the risk of systematic biases when referring to different firms' patents, because we are accounting for all patents that are valuable enough to merit applying for a U.S. patent.

This procedure allows us to compute three measures. The first is number of founder patent citations - all backward citations found in a firm's focal year's citations to patents that specify founders as inventors/contributors. The second measure is number firm member patent citations - all backward citations found in a firm's focal year's citations to patents that specify non-founder firm members as inventors or contributors. We identify firm members as non-founding employees who were part of the top management team or appeared in various documents (e.g. prospectuses or press releases) as employees of a focal firm. The third measure is number of external stakeholder patent citations - all backward citations, found in a firm's focal year's citations, to patents that specify inventors or contributors who either owned or were employed by external stakeholders of the firm (specifically suppliers, customers, or partners). We identified external stakeholders according to press announcements where a focal firm's suppliers, customers, and partners had been mentioned and then used available data on owners and employees (from datasets, prospectuses or press releases) to identify specific persons as owners or employees of such suppliers, customers, or partners of a focal firm. ${ }^{5}$ We used a similar procedure to calculate the citations to all other patents (i.e. not of founders, firm members or external stakeholders), denoted as number of other patent citations.

\footnotetext{
${ }^{4}$ Yet, due to data availability we refer to backward citations listed in the granted patents. As the final patents state more accurately and comprehensively the true knowledge sources of firms (Cotropia, Lemley and Sampat, 2013), this mitigates firm-specific motivations to either cite or not cite themselves or others.

${ }^{5}$ To corraborate our measures we randomly approached 10 percent of the sampled firms (15 firms) and checked whether there were biases or ommissions in the identification of founders, firm members and external stakeholders as sources of technoloigcal knowledge (on an annual basis). The correlation between this procedure and the one described above for these firms was extremly high (0.937), lending support for our procedure for calaculating the knowlede origins of the sample firms.
} 
For the number of product introductions of the sample firms, we developed a count measure for a firm's number of new product introductions in each year (these product introductions were typically within each firm's core six-digit NAICS industry). In the high technology sector it is important to verify that products differ in their technological specifications and design (Katila and Ahuja, 2002) and are not simply newer models of old product versions. First, we tracked down the number of products for each firm at its inception. Next, we used press announcements to identify any new product introductions by each firm. Determining what constituted a new product (rather than a new model of an existing product) was based on the guidelines of a panel of high technology industry experts. These industry experts first examined the product announcements independently (based on their experience, the data in the press announcement, and web-based information) and then discussed their classifications together. Each announcement was examined by two experts. In cases where the industry experts were not in agreement in their individual classifications (less than 10 percent of the cases, reflecting an inter-rater reliability of 0.792 ), they reached mutual agreement as to what constituted a new product introduction and what was a new model of an existing product. In a small number of cases, the firms' senior management was contacted to request clarifications on their different products. Overall, about 3,000 press announcements of new and existing products were examined for the sampled firms.

We use firm age to capture changes over time. Firm age is calculated on an annual basis for each sampled firm. We further use dummies for the stage of development of newly established high technology firms, relating to four stages (seed, R\&D, initial sales and sales growth) as an alternative to firm age. These stages are used by IVC to portray the development of startup firms as of their inception.

\section{Descriptive Statistics}

Descriptive statistics of our data are presented in Table 1. Overall, we have examined 907 patents with about 41,500 citations. On average, the sample firms had about 46 overall backward citations per year. Out of these citations, 4.6 citations per year were to previous patents where one of the firm founders is an inventor or contributor (representing a 10\% share of annual firm backward citations), 1.8 citations per year were to previous patents where firm members are inventors or contributors (3.9\% of annual 
firm backward citations), and 1.6 citations were to previous patents assigned to external stakeholders (3.5\% of annual firm backward citations). The sample firms introduced about 1.4 new products per year (accumulating to a product portfolio that averaged at around 6.6 products) and they are fairly young (about 5.8 years old). The correlations between the different measures are generally low to medium, other than the correlation between the number of inventing firm members and the number of firm member patents $(\mathrm{r}=.79)$.

[Insert Table 1 about here]

\section{Patent Citations Patterns}

We plot the patterns of patent citations over firm age and stage of development to shed light on the shifts in the sources of technological knowledge among our sample firms. Figures 1a and $1 \mathrm{~b}$ present these patterns as of firm inception and for an ensuing period of 11 years (about one standard deviation above the average age of the sample firms). Figure 1a shows that the propensity to backward cite founder patents peaks at around two years after inception and further reveals a (lower) peak in the propensity to backward cite firm member patents at around four years after inception. Notably, in terms of absolute numbers, the firms' citations of firm member patents ultimately equal their citations of founder patents. This happens about ten years after firm inception. The figure also shows a steady increase in the propensity to backward cite external stakeholders, where about eleven years after firm inception the absolute number of citations of external stakeholder patents becomes equal to and then surpasses the combined citations of founder and firm member patents.

Figure $1 b$, shows the per firm number of backward citation to founder, firm member and external stakeholder patents for the four typical development stages of high technology new firms seed investments, R\&D activities, initial sales and sales growth (Kazanjian, 1988). Relating to stage of development rather than firm age allows us to account for inter-firm differences in the pace of development. The figure shows a consistent pattern with that presented in Figure 1a as the propensity to cite founders peaks at the seed stage, the propensity to cite firm members peaks at the R\&D stage, and at the sales growth stage the propensity to cite external stakeholders exceeds the combined propensity to cite founders and firm members. 
Finally, Figure 1c adds information about the trend in citing patents of other origin, i.e. those patents that are not of founders, firm members or external stakeholders (constituting just below $82 \%$ of the total number of citations). As discussed above, these citations relate to technological knowledge that is commonly known and disseminated and that the sample firms cite either voluntarily or due to the requirements of the patent examiners (Cotropia, Lemley and Sampat, 2013). As expected, reliance on this type of technological knowledge does not show any systematic trend over time, but rather fluctuates between 20 and 25 annual backward citations per firm. This observation supports our assumption that, while representing the bulk of firm backward citations, this type of citations does not systematically vary in its influence over newly established high technology firms over time.

[Insert Figures 1a, 1b, 1c about here]

Next, we wanted to assess whether the observed patterns of patent citations over firm age result from changes in the number of inventors or in the number of patents applied for by founders, firm members and external stakeholders. Assessing such possible effects would allow greater confidence in refuting the hypothesis that the patterns observed in figures 1a-1c derive from changes in the number of inventors in each group or in the number of patents each group of inventors applies for, over the development of our sample firms. For example, the change in the number of citations to founder patents may result from a decrease in the number of founder inventors as these leave their firm's top management team. To address these possibilities, we first plotted the number of inventors who are founders, firm members or belong to external stakeholders over firm age. Next, we plotted the number of patents applied for, at a given firm age, by founders, firm members and inventors in external stakeholders to capture whether changes in the respective numbers of patents are likely to influence citations patterns. For example, a higher number of patents applied for by a given group (be it founders, firm members or external stakeholders) may increase the number of patent citations to this group.

Figures $2 \mathrm{a}$ and $2 \mathrm{~b}$ respectively show the number of inventors and patenting over firm age. Figure 2a shows a slight decrease in the number of inventing founders, which may be expected as sometimes founders leave their firms or cease to engage in technology creation. It further shows an increase in the number of inventing firm members. Finally, the number of per firm external stakeholder inventors fluctuates over time, but is more or less constant (averaging 12 external stakeholder inventors per 
firm). Figure $2 b$ reveals a more or less steady pattern of founder patenting with a moderate decrease over time. It further shows an initial increase in the number of firm member patents and in the number of external stakeholder patents (up to around three years after inception) which then remains about unchanged. Taken together, the underlying patterns number of inventors and patenting do not seem to provide a good explanation for the trends observed in patent citations, and especially not the peaks in the propensity to cite patents by founders and firm members. Given these patterns, we contend that one can refute the argument that changes in the observed patterns of patent citations over firm age are driven by changes in the number of inventors or the number of patents applied for by founders, firm members and external stakeholders

[Insert Figures 2a, 2b about here]

\section{Patent Citations and New Product Introductions Patterns}

Next, we turn to examine whether the observed patterns of patent citations for founder, firm member and external stakeholder patents influence new product introductions. In this case, we aim to explore whether firms that vary in their propensity to cite founders, firm members and external stakeholders, at different points of time, vary in their propensity to introduce new products. Figures $3 \mathrm{a}$ and $3 \mathrm{~b}$ respectively present the change in number of (per year) new product introductions over firm age and stage of development. On average, we can see a steady increase in the number of new product introductions. More interesting is the distribution of product introductions for firms varying in their propensity to cite founders, firm members and external stakeholders. Figure 3 a shows that firms that cite founder patents above the sample average (at a given age) tend to initially have a higher number of product introductions, but between three to four years after inception these firms start lagging the sample firms' average new product introduction rate. In contrast, firms who cite firm members' patents above the average tend to initially lag in terms of new product introductions, but after around four years they start to introduce more products than the sample average. A similar pattern applies also for firms who cite external stakeholders above the average, where the tipping point also occurs after around four years. The examination of new product introductions at the initial sales and sales growth stages (Figure 3b) is consistent with the above pattern, as firms with a high propensity to cite founders exceed all other firms in their new product introductions at the initial sales stage, but lag other firms at 
the sales growth stage. In contrast, firms with a high propensity to cite firm members or external stakeholders lag behind other firms in their new product introductions at the initial sales stage but exceed them at the sales growth stage.

[Insert Figures 3a, 3b about here]

Overall, the plots reveal systematic patterns in backward patent citations among our sample firms, which do not seem to be explained by developments in terms of numbers of inventors or patenting. These citation patterns include an early peak in the propensity to cite the patents of founders, a later peak in the propensity to cite patents of other firm members and a steady increase in the propensity to cite patents of external stakeholders. They also reveal a connection between the propensity to cite these three sources of technological knowledge and the rate of new product introductions, where a greater propensity to cite founder rather than firm member or external stakeholder patents is initially associated with a higher number of new product introductions, but a lower number of new product introductions later on.

\section{Robustness Analyses}

We conducted several additional robustness analyses to corroborate our results. First, we checked whether the trends in the reliance of newly established high technology firms on different sources of technological knowledge result from systematic patterns of presence or non-presence of founders in the top management teams (TMTs) of their firms (Wasserman, 2003, 2016; Chen and Thompson, 2015). To account for the potential selection bias in our dataset we employed a Coarsened Exact Matching (CEM) estimation. In our CEM models, a first-stage regression was fitted to estimate the probability of firms to be "treated" by a departure of all founders from the TMT. ${ }^{6}$ Doing this allowed us to construct a sub-sample of 754 firm-year observations with treated firms and matched control firms (where founders had not departed from the TMT). Reassuringly, for both groups in this sample the same patent citation trends identified in Figure 1a were observed, with a slightly lower propensity to cite founder patents among those firms where founders had departed from their top management teams.

${ }^{6}$ In 31 percent of the firms, all founders had departed from the TMT at some point. 
Next, we also examined whether the trends we observe hold only for patents where a focal sample firm is the patent assignee (excluding citations to patents of founders and firm members that had other assignees, e.g. where patenting occurred while founders or firm members were working in another firm). For this more restrictive approach to both founder patent citations and firm member patent citations the patterns observed in Figure 1a remain the same, with a peak in the propensity to cite founder patents after about two years and a peak in the propensity to cite firm member patents after about four years.

To further assess the possibility that our results are driven by other demands on founders' or firm members' time, we plotted the patent citations and new product introductions for firms where any of the founder inventors (in a given year) took a non-technological managerial role in their firms, and where any of the inventing firm members in our data took such a role. The revealed patterns remain consistent with our main results. In another analysis of firm-specific patterns, we re-plotted the data while considering only backward citations to firm member patents (rather than all patents where the focal firm is the assignee) and received results consistent with the trend of Figure 1a. The results from this analysis, which essentially eliminates founders' patents, reduces the suspicion that it is the tendency of founders to cite themselves that drives our results, and supports the notion that the reported trends and patterns reflect a wider firm-level phenomenon.

In addition, we tried to see whether we could identify temporal patterns in the reliance on different types of external stakeholders. We could not observe any difference between the propensity of firms to rely on their partner technological knowledge (69\% of stakeholder citations), suppliers ( $22 \%$ of stakeholder citations) and customers ( $9 \%$ of stakeholder citations). Furthermore, our main analyses do not take into account the fact that some of the cited patents may include both founders and firm members, firm members and external stakeholders, or any other combinations of these subgroups. For patents like these it is unclear to whom the origination of knowledge should be attributed. To confront this potential bias, we excluded from the analyses citations to patents where such combinations existed (19 percent of the total number of founder, firm member and external stakeholder patents cited), thus retaining only patent citations where either founders, firm members or external stakeholders were solely listed as inventors or contributors. The results of this procedure 
remained fully consistent with our main results. To assess the possibility that the decline in founder and firm member patent citations results from the fact that their patents become more dated over time, we further checked whether our results hold when analyzing citations only to more recent patents. We therefore confined the analysis of cited patents to those that were up to five years old (at the year of citation) and patents that were up to three years old. In both cases there were no significant changes to our observed patterns.

Finally, two important concerns related to the association we find between the propensity of firms to cite different sources of technological knowledge and their new product introductions relate to the causality of this effect and to the potential endogeneity in the association between reliance on different sources of technological knowledge and new product introductions. For instance, if a set of new products the firm introduces in a given year has originated from a specific source of technological knowledge (be it founders, firm members or external stakeholders), the existence of such a set may drive further reliance of the same source(s) of knowledge. Alternatively unobserved firm-specific factors may affect both the reliance on different sources of knowledge and new product introductions. To account for such possible endogeneity issues, we applied the general method of moments (GMM) introduced by Arellano and Bond (1991). We ran regressions with the lagged values of the dependent variable (number of product introductions) and the potentially endogenous explanatory variables (number of founder patent citations, number of firm member patent citations and number of stakeholder patent citations) from t-2 as instruments. ${ }^{7}$ These regressions provided results that are consistent with Figure 2a. In early firm years, we observe a stronger effect of the number of founder patent citations on new product introductions than the effects of the number of firm member patent citations and the number of stakeholder patent citations. However, later on, as firms develop, the effect of the number of founder patent citations on new product introductions diminishes, while the effects of the number of firm member patent citations and the number of stakeholder patent citations remains positive.

\footnotetext{
${ }^{7}$ In these regressions, we controlled for a large number of additional variables, including: overall number of founders/firm members/stakeholders/other citations, founder/firm member industry specific and non-industry specific experience, firm sales, R\&D intensity, investments made in the firm and market size. More details on these regressions and on an extensive set of additional regressions are provided in the online appendix.
} 


\section{DISCUSSION}

Taken together, the empirical findings reveal some interesting features of high technology firms in their early years of development. In terms of the technological knowledge that is instrumental for creating and defining these firms, our analyses indicate that they move rapidly across different sources of technological knowledge. During the first years of operation, internal sources of technological knowledge, in particular the knowledge of founders but after a few years also that of other firm members, are significantly more important than technological knowledge of external stakeholders. Among the high technology firms in the current sample, the firms' reliance on internal sources of technological knowledge and the reliance on external stakeholders become about equal after some ten years. $^{8}$

The findings also suggest that in terms of new product introductions the reliance of newly established high technology firms on different sources of technological knowledge exhibits non-trivial temporal effects. Such firms depend on their founders as a critical initial source of knowledge for expanding their product offering (Stern and Henderson, 2004; Kaplan et al., 2009). Although firm members increasingly contribute more technological knowledge to the development of their firms, our empirical findings suggest that in the first few years they cannot fully replace the founders in the process of generating new products. On the other hand, after a few defining years, firms that continue to rely on founders as a dominant source of technological knowledge, rather than on firm members or external stakeholders, face a future that involves comparatively fewer new product introductions. From this perspective, and to the extent a broad product portfolio helps diversify risk and attract external capital, the results indicate that firm founders are a boon but may also turn into something of a drogue in the development of new high technology firms.

\section{Dynamics in Technological Knowledge Origins}

The observed dynamics in the origins of technological knowledge extend extant research on the relationship between technological knowledge and the development of high technology firms in several ways. It is evident from the results that in their early years newly established high technology

\footnotetext{
${ }^{8}$ It is noteworthy that even in their very early years our sample firms rely mostly on other external sources of technological knowledge (see Figure 1c).
} 
firms critically depend on the technological knowledge of individual founders (Baron, Burton and Hannan, 1996; Burton, 2001; Colombo and Grilli, 2005). Interestingly, during the first years of development our sample firms experience a pronounced peak in the reliance on founder technological knowledge. This period of intensive reliance on founder technological knowledge is likely to be defining to the firm's development, and in absolute terms the influence of founder technological knowledge continues to dominate firm member and external stakeholder technological knowledge for about six years. After that, however, the importance of founder technological knowledge is superseded by the technological knowledge and influences of other firm members and, later on, by the technological knowledge of external stakeholders.

The observed dominance of founder technological knowledge during the early development of new high technology firms suggests that the operations of such firms are to a more limited extent determined by knowledge residing among firm members and embedded in social relationships, as predicated by the knowledge based view of the firm (Kogut and Zander, 1992; Grant, 1996). The observed shifts in the sources of technological knowledge suggest that throughout early firm years a large share of firm knowledge originates from a limited number of founding individuals, and that technological knowledge that is dispersed within the organization remains secondary to founder knowledge for several years after firm inception. Our results nonetheless show that over and above the increasing number of firm members, their technological knowledge becomes steadily more important to newly established high technology firms (albeit not as much as that of founders) over the first years of firm development. Although we can only speculate about the underlying drivers of such increased reliance on firm member technological knowledge, overall our observations point to the existence of an employee-led 'second wave' of impactful technological knowledge in the development of new high technology firms.

Our observations finally emphasize the gradually increasing importance of external stakeholder technological knowledge throughout the development of newly established high technology firms. Stakeholder technological knowledge nevertheless appears to play a secondary role in the initial development of newly established high technology firms. In the current sample, it takes about ten years before in absolute terms the importance of external stakeholder technological 
knowledge comes to equal that of founders and firm members. Still, the monotonically increasing contribution from external stakeholder technological knowledge suggests that at some point it will come to surpass the contribution from the erstwhile dominant internal knowledge sources.

\section{Processes of technological knowledge formation}

The observations at hand allow us to outline a framework that captures what could be prominent interlinkages between evolving sources of technological knowledge in new high technology firms. As noted above, the reliance of new high technology firms on their founders' technological knowledge initially increases and reaches a peak at around two years after firm inception. During this period, it is likely that founders leverage their prior and evolving technological knowledge by establishing priorities and directions for technological development, and as part of this, to a significant degree direct the tasks to be performed by other firm members (Kazanjian, 1988; Zander, 2007).

Yet, the founders' significant role and involvement in the early development of newly established high technology firms is accompanied by a steady increase in the contribution of technological knowledge from other firm members. This shift would be driven by other firm members who become involved in technological development activities together with the founders, thereby gaining experience-based technological knowledge (Huber, 1991). It would also include the hiring of a growing number of firm members with complementing technological knowledge (Almeida and Kogut, 1999). What started as founders' knowledge about technological frames is thus gradually transformed into more dispersed technological knowledge within the firm (Dougherty, 1992; Liebeskind, 1996). It is only then that the combinative capabilities of maturing high technology firms can become more fully utilized (Kogut and Zander, 1992; Galunic and Rodan, 1998; von Krogh, Ichijo and Nonaka, 2000; Smith, Collins and Clark, 2005).

The observed dynamics in the sources of technological knowledge further suggest that, over time, as founders and later other firm members interact and become involved in communicating with external stakeholders, newly established high technology firms also increasingly come to rely on these stakeholders' technological knowledge (Almeida et al., 2003; Dyer and Nobeoka, 2000). As contacts with external stakeholders such as suppliers, customers, and partner firms deepen throughout the firm's development, they ultimately come to significantly shape and extend the technological 
knowledge that defines the firm (Ahuja, 2000; Cassiman and Veuglers, 2006; Laursen et al., 2010;

Phelps, 2010; Zhou and Li, 2012; Arora, Belenzon and Rios, 2014).

\section{Technological Knowledge Origin Dominancy and the Introduction of New Products}

Our findings reveal that greater initial reliance on technological knowledge originating from firm founders has a positive effect on the number of new product introductions. Conversely, after a number of years greater reliance on technological knowledge sources that generally become more prominent later on in firm development, specifically technological knowledge originating from other firm members and external stakeholders, has an accentuated positive effect on new product introductions.

These observations suggest that in the early days of high technology firms, the pursuit of new product ideas is most effective if it is connected to founders' technological knowledge (Ronstadt, 1988; Shan, 1990; Stern and Henderson, 2004). Although over time other firm members and external stakeholders start contributing to the development of original technologies and products, our findings suggest that, at least initially, relying on their technological knowledge is less effective in terms of generating new product introductions. However, as firms develop, it appears that sustained reliance on the technological knowledge of founders ultimately limits new product introductions. Such sustained high reliance on founder knowledge could result from founder efforts to stay in control over new product introduction, as in many cases they see themselves as uniquely qualified to pursue their mission and lead the company (Wasserman, 2003). From this perspective, and to the extent a broad product portfolio helps diversify risk or attract external capital, it appears that firm founders are of critical importance but may ultimately turn into something of a drogue in the development of new high technology firms.

\section{Limitations and Further Research}

Our findings reveal systematic shifts in the sources of technological knowledge and parallel associations with the number of product introductions in high technology firms during their early years, but several questions remain to be answered. In the present study, we have not assessed performance implications beyond the effects of knowledge sources on the number of product introductions. Notably, the number of new product introductions may conceal significant differences 
in the quality and profitability of individual new product launches, and hence cannot be considered an encompassing performance measure.

It must also be remembered that on average we follow the sample firms over a limited number of years, and that any shifts in the sources of technological knowledge and associated effects on the introduction of new products after that remain unexplored. For instance, Sorenson and Stuart (2000) found that firms operating in the semiconductor industry rely more on internal sources of technological knowledge when they grow older. Yet, they study firms that are much older than our sample firms (average sample age is 18.5 years, relative to less than 6 years in our sample). They nevertheless also find that the same trend occurs at a younger age for biotechnology firms, which are absent from our sample. ${ }^{9}$ This suggests that future studies should continue to explore industry-dependent variation in the reliance of firms on different sources of technological knowledge over extended time periods.

We further emphasize that the results may be biased in that the empirical evidence mainly includes observations from successful and surviving firms. This is a common complication in the study of new ventures (Beckman and Burton, 2008; Kaplan, Sensoy and Strömberg, 2009), and raises the question of deviating patterns among firms that experience early failure. The hypothesis that high technology new ventures that fail to survive the initial development stages are associated with significantly different pathways in their use of technological knowledge remains to be addressed in future studies.

Further research would be necessary also for producing more detailed insights into the explanations for the findings we get. In particular, the dynamics behind the two observed peaks in the reliance on founder and firm member technological knowledge call for closer investigations, as does the positive effect of firm member technological knowledge on new product introductions in later stages of firm development. Furthermore, our theoretical framework is but a first attempt to outline the interconnections between evolving sources of technological knowledge in newly stablished high technology firms, which needs to be validated through more fine-grained research. Why sustained high

\footnotetext{
${ }^{9}$ It is noteworthy that, unlike the current study, Sorenson and Stuart (2000) do not distinguish between founders and non-founder firm members, nor between external stakeholders and other external sources of technological knowledge.
} 
levels of founders' technological knowledge ultimately limits new product introductions is another still only partially answered question of significant practical and strategic importance for new high technology firms. Investigations such as these nevertheless require refined data, and may be more effectively approached through qualitative research designs. Such designs would allow for closer examinations of how, for example, changes in organizational structures and job roles affect technological innovation and new product introductions, and are beyond the scope of the current study.

\section{SUMMARY AND CONCLUSIONS}

Our study has identified distinctive trends in the propensity of newly established high technology firms to rely on founder, firm member and external stakeholder technological knowledge, and that these trends have significant effects on new product introductions. It joins a growing stream of research that concerns itself with the use and effects of technological knowledge in early firm years (Dencker et al., 2009; Fern et al., 2012; Gruber, MacMillan and Thompson, 2013). This literature aims to fill a significant empirical and conceptual gap in our understanding of the expansion and scaling up of new high technology firms, specifically with regard to utilized sources of technological knowledge and the dynamics of new product introductions. How founder technological knowledge evolves alongside firm member and external stakeholder knowledge most likely holds one of the keys to developing this understanding. 


\section{REFERENCES}

Ahuja, G. 2000. Collaboration networks, structural holes, and innovation: A longitudinal study. Admin. Sci. Quart., 45(3): 425-455.

Aldrich, H.E., Ruef, M. 2006. Organizations Evolving (2 ${ }^{\text {nd }}$ Edition). London: Sage Publications.

Almeida, P., Kogut, B. 1999. Localization of knowledge and the mobility of engineers in regional networks. Management Sci., 45(7): 905-918.

Almeida, P., Dokko, G., Rosenkopf, L. 2003. Startup size and the mechanisms of external learning: Increasing opportunity and decreasing ability? Res. Policy., 32(2), 301-315.

Arellano, M, Bond, SR. 1991. Some tests of specification for panel data: Monte Carlo evidence and an application to employment equations. Rev. of Econ. Stud., 58(2): 277-297.

Arora, A., Belenzon, S., Rios, L.A. 2014. Make, buy, organize: The interplay between research, external knowledge, and firm structure, Strategic Management J. 35: 317-337.

Baron, J.N., Burton, M.D., Hannan, M.T. 1996. The road taken: Origins and evolution of employment systems in emerging companies. Indust. and Corporate Change, 5(2): 239-275.

Beckman C.M., Burton M.D. 2008. Founding the future: Path dependence in the evolution of top management teams from founding to IPO. Organ. Sci., 19(1): 3-24.

Bosma, N., Levie, J. 2009. Global Entrepreneurship Monitor - 2009 Global Report.

Brown, J.S., Duguid, P. 2001. Knowledge and organization: A social-practice perspective. Organ. Sci., 12(2): 198-213.

Burgelman, R.A. 1983. A process model of internal corporate venturing in the diversified major firm. Admin. Sci. Quart., 28(2): 223-244.

Burton, M.D. 2001. The company they keep: Founders' models for organizing new firms. In Schoonhoven, C.B. \& Romanelli, E. (eds), The Entrepreneurship Dynamic - Origins of Entrepreneurship and the Evolution of Industries. Stanford, CA: Stanford University Press.

Cassiman B., Veugelers, R. 2006. In search of complementarity in innovation strategy: Internal R\&D and external knowledge acquisition. Management Sci., 52(1): 68-82.

Chen, J, Thompson, P. 2015. New firm performance and the replacement of founder-CEOs. Strategic Entrepreneurship J., 9(3): 243-262.

Chesbrough, H. 2003. Open innovation. Harvard Business School Press, Boston, MA.

Colombo, L.G., Grilli L. 2005. Founders' human capital and the growth of new technology-based firms: a competence-based view. Res. Policy, 34(6): 795-816.

Cotropia, C.A., Lemley, M.A., Sampat, B. 2013. Do applicant patent citations matter? Res. Policy, 42(4): 844-854.

Dencker, J.C., Gruber, M. 2015. The effects of opportunities and founder experience on new firm performance. Strategic Management J., 36(7): 1035-1052. 
Dencker, J.C., Gruber, M., Shah, S.K. 2009. Pre-entry knowledge, learning, and the survival of new firms. Organ. Sci., 20(3): 516-537.

Dougherty, D. 1992. A practice-centered model of organizational renewal through product innovation. Strategic Management J., 13(S1): 77-92.

Dyer, J.H., Nobeoka, K. 2000. Creating and managing a high-performance knowledge-sharing network: The Toyota case. Strategic Management J., 21(3): 345-367.

Fauchart, E., Gruber, M. 2011. Darwinians, communitarians, and missionaries: The role of founder identity in entrepreneurship. Acad. of Management J., 54(5): 935-957.

Fern, M.J., Cardinal, L.B., O’Neill, H.M. 2012. The genesis of strategy in new ventures: Escaping the constraints of founder and team knowledge. Strategic Management J., 33(4): 427-447.

Franke, N., Shah, S. 2003. How communities support innovative activities: An exploration of assistance and sharing among end-users. Res. Policy, 32(1): 157-178.

Galunic, D.C., Rodan, S. 1998. Resource recombinations in the firm: Knowledge structures and the potential for Schumpeterian innovation. Strategic Management J., 19(12): 1193-1201.

Grant, R.M. 1996. Toward a knowledge-based theory of the firm. Strategic Management J., 17(S2): 109-122.

Gruber, M., MacMillan, I.C., Thompson, JD. 2013. Escaping the prior knowledge corridor: What shapes the number and variety of market opportunities identified before market entry of technology start-ups? Organ. Sci., 24(1): 280-300.

Håkanson, L. 2007. Creating knowledge: the power and logic of articulation. Indust. and Corporate Change, 16(1): 51-88.

Hashai, N. 2015. Within-industry diversification and firm performance-An S-shaped hypothesis. Strategic Management J. 36(9): 1378-1400.

Helfat, C., Raubitschek, RS. 2000. Product sequencing: Co-evolution of knowledge, capabilities, and products. Strategic Management J., 21(10/11): 961-979.

Huber, G.P. 1991. Organizational learning: the contributing processes and the literatures. Organ. Sci., 2(1):88-115.

Kale, P., Singh, H., Perlmutter H. 2000. Learning and protection of proprietary assets in strategic alliances: Building relational capital, Strategic Management J., 21(3): 217-237.

Kaplan, S., Tripsas, M. 2008. Thinking about technology: Applying a cognitive lens to technical change. Res. Policy, 37(5): 790-805.

Kaplan, S.N., Sensoy, B.A., Strömberg, P. 2009. Should investors bet on the jockey or the horse? Evidence from the evolution of firms from early business plans to public companies. J. of Finance, 64(1): 75-115.

Katila, R., Ahuja, G. 2002. Something old, something new: A longitudinal study of search behavior and new product introduction. Acad. of Management J., 45(6): 1183-1194.

Kazanjian, R.K. 1988. Relation of dominant problems to stages of growth in technology-based new ventures. Acad. of Management J., 31(2): 257-279. 
Kirzner, I.M. 1985. Discovery and the Capitalist Process. Chicago and London: The University of Chicago Press.

Kogut, B., Zander, U. 1992. Knowledge of the firm, combinative capabilities, and the replication of technology. Organ. Sci., 3(3): 383-397.

Kogut, B., Zander, U. 1996. What firms do? Coordination, identity and learning. Organization Science, 7(5): 502-518.

Laursen, K., Salter, A. 2006. Open for innovation: The role of openness in explaining innovation performance among U.K. manufacturing firms. Strategic Management J., 27(2): 131-150.

Laursen, K., Leone, M.I., Torrisi, S. 2010. Technological exploration through licensing: New insights from the licensee point of view. Indust. and Corporate Change, 19(3): 871-897.

Liebeskind, J.P. 1996. Knowledge, strategy, and the theory of the firm. Strategic Management J., 17(S2): 93-107.

Mallapragada, G., Grewal, R., Lilien, G. 2012. User-generated open source products: Founder's social capital and time to product release. Marketing Sci., 31(3): 474-492.

Mowery, D.C., Oxley, J.E., Silverman, B.S. 1996. Strategic alliances and inter-firm knowledge transfer. Strategic Management J., 17(52): 77-91.

Nickerson, J.A., Zenger, T.R. 2004. A knowledge-based theory of the firm: The problem solving perspective. Organ. Sci., 15(6): 617-632.

Phelps, C.C. 2010. A longitudinal study of the influence of alliance network structure and composition on firm exploratory innovation. Acad. of Management J., 53(4): 890-913.

Riggs, W., von Hippel, E. 1996. Incentives to innovate and the sources of innovation: The case of scientific instruments. Res. Policy, 23(4): 459-469.

Ronstadt, R. 1988. The corridor principle. J. of Bus. Venturing, 3(1): 31-40.

Sampson, R.C. 2007. R\&D alliances and firm performance: The impact of technological diversity and alliance organization on innovation. Acad. of Management J., 50(2): 364-386.

Saxenian, A.L. 1994. Regional Advantage. Cambridge, MA: Harvard University Press.

Schumpeter, J.A. 1934. The Theory of Economic Development: An Inquiry into Profits, Capital, Credit, Interest and the Business Cycle $\left(7^{\text {th }}\right.$ printing, 1961). Cambridge, MA: Harvard University Press.

Senor, D., Singer S. 2011. Start-Up Nation: The Story of Israel's Economic Miracle. New York: Twelve, Hachette Book Group.

Shan, W. 1990. An empirical analysis of organizational strategies by entrepreneurial high-technology firms. Strategic Management J., 11(2): 129-139.

Shane, S. 2000. Prior knowledge and the discovery of entrepreneurial opportunities. Organ. Sci., 11(4): 448-469. 
Smith, K.G., Collins, C.J., Clark, K.D. 2005. Existing knowledge, knowledge creation capability, and the rate of new product introduction in high-technology firms. Acad. of Management J., 48(2): 346357.

Sorenson, J.B., Stuart, T.E. 2000. Aging, obsolescence and organizational innovation. Admin. Sci. Quart., 45(1): 81-112.

Stern, I., Henderson, A.D. 2004. Within-business diversification in technology-intensive industries. Strategic Management J., 25(5): 487-505.

Stuart, T.E. 2000. Interorganizational alliances and the performance of firms: A study of growth and innovation rates in a high-technology industry. Strategic Management J., 21(8): 791-811.

Von Hippel, E. 1976. The dominant role of users in the scientific instrument innovation process. Res. Policy, 5(3): 212-239.

Von Hippel, E. 1988. The Sources of Innovation. Oxford: Oxford University Press.

Von Krogh, G., Ichijo, K., Nonaka, I. 2000. Enabling Knowledge Creation - How to Unlock the Mysteries of Tacit Knowledge and Release the Power of Innovation. Oxford: Oxford University Press.

Wasserman, N. 2003. Founder-CEO succession and the paradox of entrepreneurial success. Organ. Sci., 14(2): 149-172.

Wasserman, N. 2016. The throne vs. the kingdom: Founder control and value creation in startups. Strategic Management J., 38(2): 255-277.

Yli-Renko, H, Autio, E, Sapienza, H.J. 2001. Social capital, knowledge acquisition, and knowledge exploitation in young technology-based firms. Strategic Management J., 22(6-7): 587-613.

Zander, I. 2007. Do you see what I mean? An entrepreneurship perspective on the nature and boundaries of the firm. J. of Management Stud., 44(7): 1141-1164.

Zander, I, Zander, U. 2005. The inside track - On the important (but neglected) role of customers in the resource-based view of strategy and firm growth. J. of Management Stud., 42(8): 1519-1548.

Zhou, K.Z., Li, C.B. 2012. How knowledge affects radical innovation: knowledge base, market knowledge acquisition, and internal knowledge sharing, Strategic Management J., 33(9): 1090-1102. 
Change in patent citations over firm age and stage of development






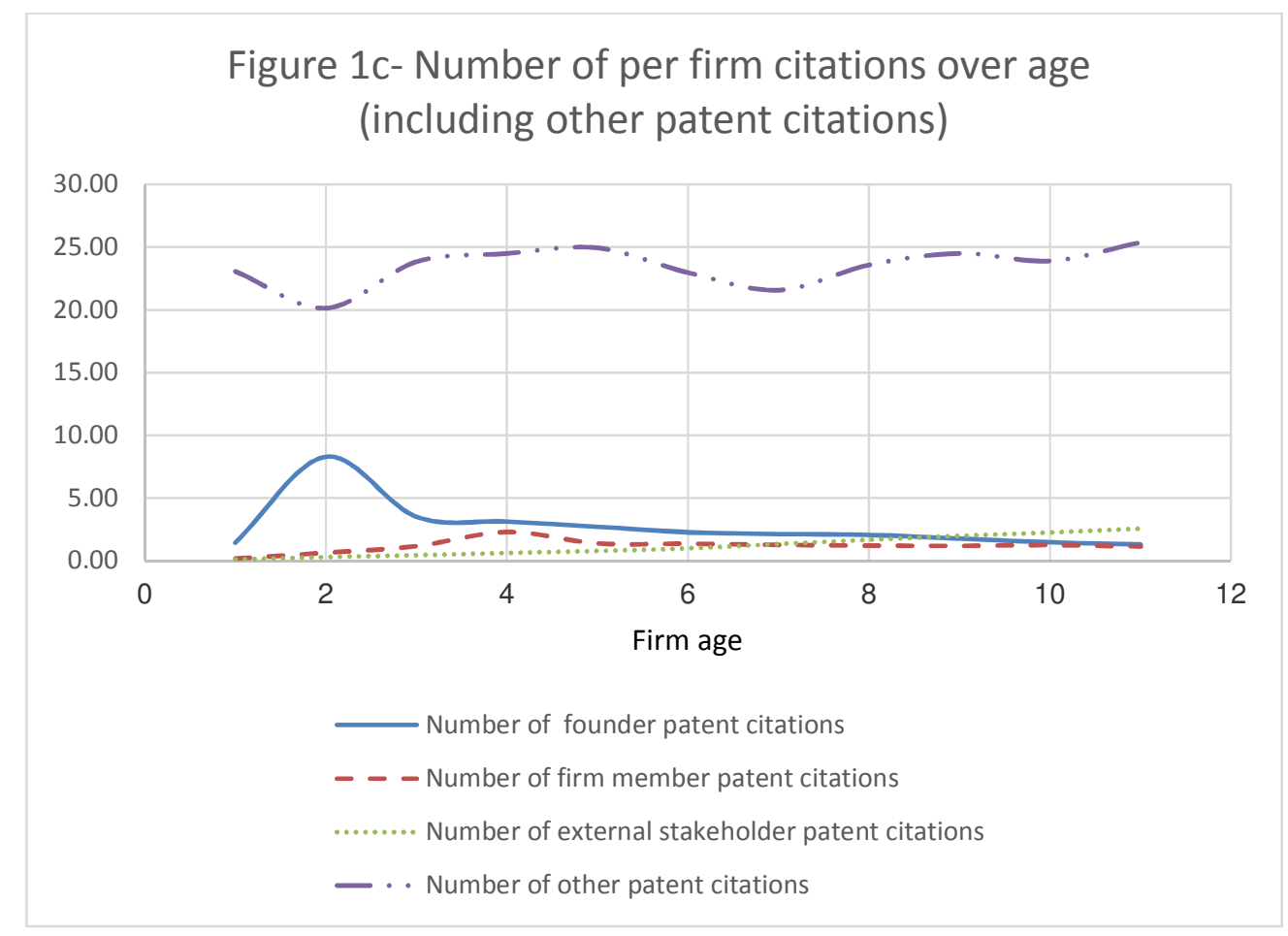




\section{Change in number of inventors and patenting over firm age}

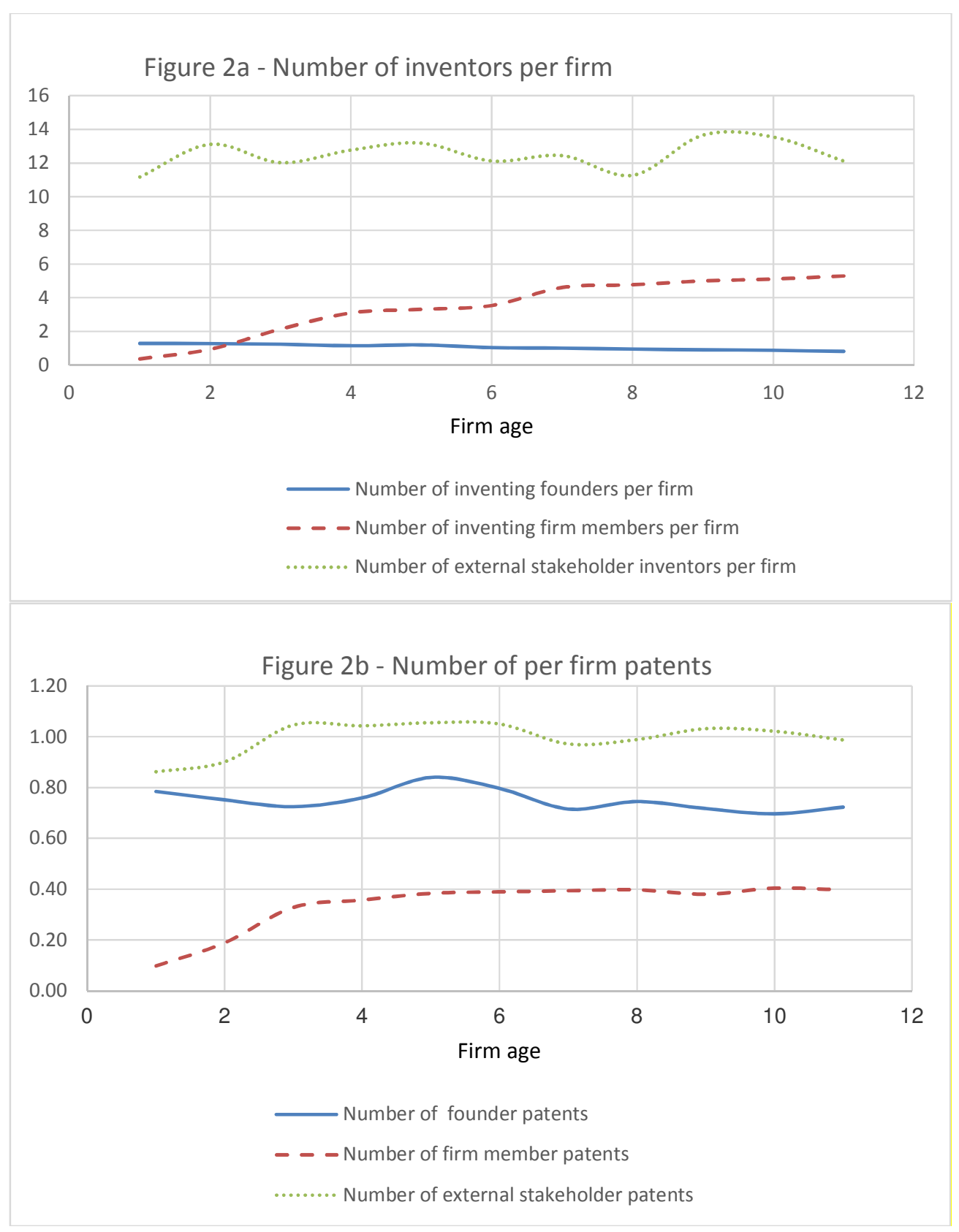




\section{Change in product introductions over firm age and stage of development}

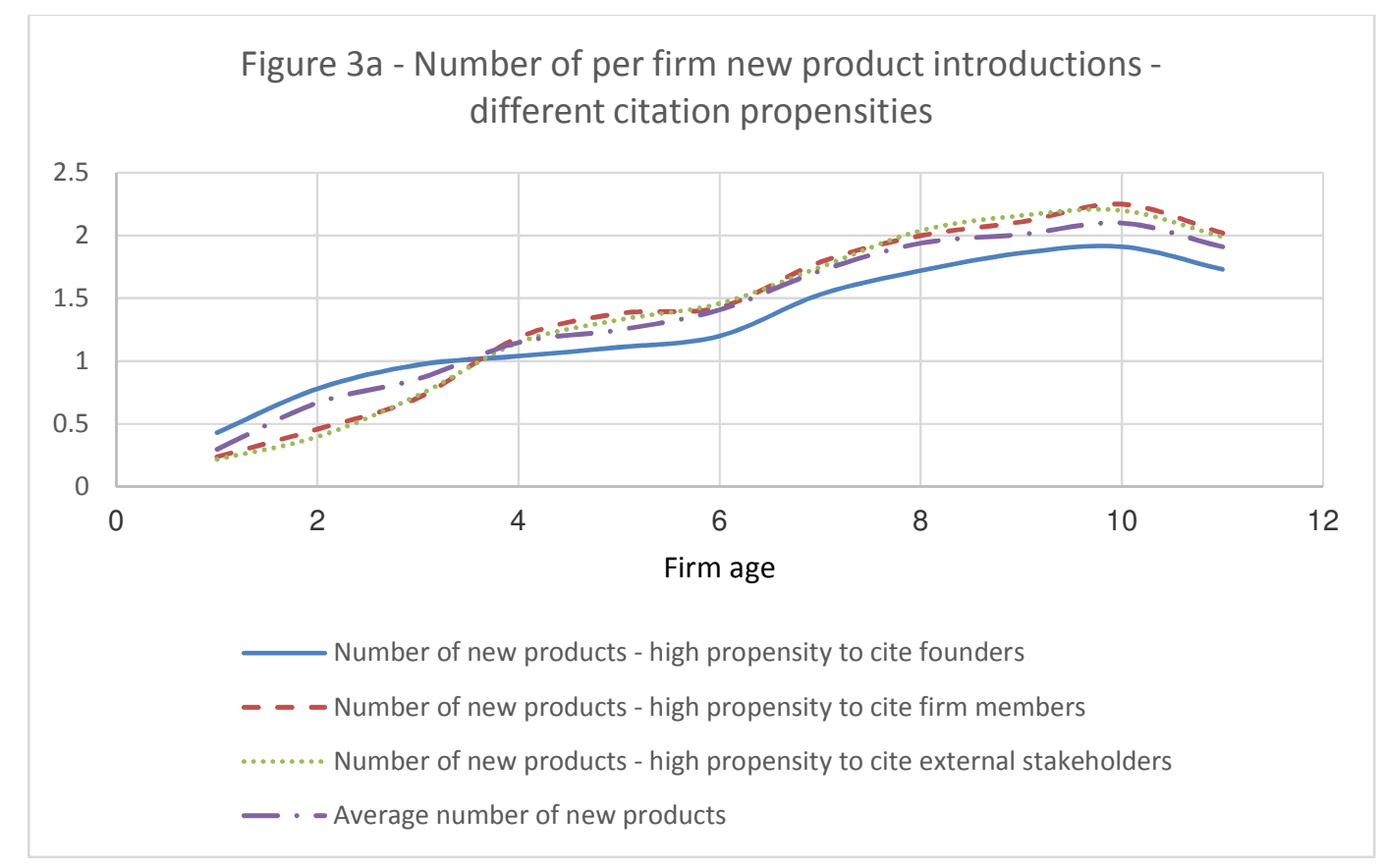

Figure 3b- Number of per firm new product introductions over stage of development

2.5

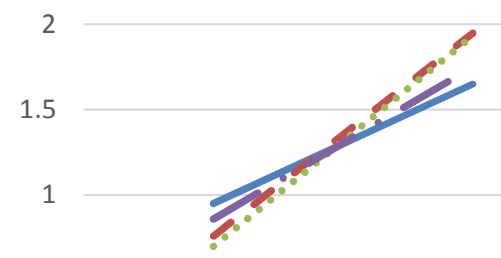

0.5

0

Initial sales Sales growth

Number of new products - high propensity to cite founders

- Number of new products - high propensity to cite firm members

..... Number of new products - high propensity to cite external stakeholders

- Number of new products 
Table 1 - Descriptive statistics and correlation matrix $(\mathbf{N}=932)$

\begin{tabular}{|c|c|c|c|c|c|c|c|c|c|c|c|}
\hline Variable & $\begin{array}{c}\text { Mean } \\
\text { (STD deviation) }\end{array}$ & 1 & 2 & 3 & 4 & 5 & 6 & 7 & 8 & 9 & 10 \\
\hline $\begin{array}{l}\text { 1. Number of } \\
\text { founder patent } \\
\text { citations }\end{array}$ & $\begin{array}{c}4.57 \\
(8.16)\end{array}$ & 1 & & & & & & & & & \\
\hline $\begin{array}{l}\text { 2. Number of firm } \\
\text { member patent } \\
\text { citations }\end{array}$ & $\begin{array}{l}1.82 \\
(2.47)\end{array}$ & -.23 & 1 & & & & & & & & \\
\hline $\begin{array}{l}\text { 3. Number of } \\
\text { external stakeholder } \\
\text { patent citations }\end{array}$ & $\begin{array}{c}1.57 \\
(2.73)\end{array}$ & -.36 & .32 & 1 & & & & & & & \\
\hline $\begin{array}{l}\text { 4. New product } \\
\text { introductions }\end{array}$ & $\begin{array}{c}1.39 \\
(1.52)\end{array}$ & -.33 & .33 & .36 & 1 & & & & & & \\
\hline 5. Age & $\begin{array}{l}5.76 \\
(5.02)\end{array}$ & -.17 & .09 & .19 & .42 & 1 & & & & & \\
\hline $\begin{array}{l}\text { 6. Number of } \\
\text { inventing founders }\end{array}$ & $\begin{array}{c}1.07 \\
(1.16)\end{array}$ & .22 & -.25 & -.29 & -.26 & -38 & 1 & & & & \\
\hline $\begin{array}{l}\text { 7. Number of } \\
\text { inventing firm } \\
\text { members }\end{array}$ & $\begin{array}{c}3.48 \\
(2.71)\end{array}$ & .24 & .28 & .35 & .15 & -.21 & -.41 & 1 & & & \\
\hline $\begin{array}{l}\text { 8. Number of } \\
\text { inventors in external } \\
\text { stakeholders }\end{array}$ & $\begin{array}{l}12.51 \\
(4.85)\end{array}$ & -.21 & .26 & .28 & .21 & .42 & -.18 & .28 & 1 & & \\
\hline $\begin{array}{l}\text { 9. Number of } \\
\text { founder patents }\end{array}$ & $\begin{array}{c}0.75 \\
(1.04)\end{array}$ & -.03 & -.17 & -.31 & -.29 & -.33 & .44 & -.34 & -.17 & 1 & \\
\hline $\begin{array}{l}\text { 10. Number of firm } \\
\text { member patents }\end{array}$ & $\begin{array}{l}0.34 \\
(1.1)\end{array}$ & -.20 & .25 & .27 & .25 & .28 & -.32 & .79 & .21 & -.24 & 1 \\
\hline $\begin{array}{l}\text { 11. Number of } \\
\text { external stakeholder } \\
\text { patents }\end{array}$ & $\begin{array}{c}0.99 \\
(2.06)\end{array}$ & -.24 & .38 & .30 & .17 & .21 & -.24 & .35 & .29 & .03 & .32 \\
\hline
\end{tabular}

Significance measures (two-tailed) of correlations above .08 are statistically significant at $1 \%$. 


\section{Appendix Table 1 - Description of variables and measures}

\begin{tabular}{|c|c|c|c|}
\hline Variable name & Variable description & Measure & Notes/data sources \\
\hline $\begin{array}{l}\text { Number of founder patent } \\
\text { citations }\end{array}$ & $\begin{array}{l}\text { The number of backward citations found in a firm's focal year's citations, to } \\
\text { patents that specify at least one founder as an inventor/contributor. }\end{array}$ & Number & $\begin{array}{l}\text { NBER U.S. Patent Citations Data File complemented by USPTO website, } \\
\text { financial reports and prospectuses, DunsGuide Global, D\&A and IVC datasets. }\end{array}$ \\
\hline $\begin{array}{l}\text { Number of firm member } \\
\text { patent citations }\end{array}$ & $\begin{array}{l}\text { The number of backward citations found in a firm's focal year's citations, to } \\
\text { patents that specify firm members as inventors/contributors. }\end{array}$ & Number & $\begin{array}{l}\text { NBER U.S. Patent Citations Data File complemented by USPTO website, } \\
\text { DunsGuide Global, D\&A and IVC datasets, financial reports and prospectuses and } \\
\text { Lexis Nexis Academic. }\end{array}$ \\
\hline $\begin{array}{l}\text { Number of external } \\
\text { stakeholder patent } \\
\text { citations }\end{array}$ & $\begin{array}{l}\text { The number of backward citations found in a firm's focal year's citations, to } \\
\text { patents that specify individuals in suppliers, partners or customers as } \\
\text { inventors/contributors. }\end{array}$ & Number & $\begin{array}{l}\text { NBER U.S. Patent Citations Data File complemented by USPTO website, } \\
\text { DunsGuide Global, D\&A and IVC datasets, financial reports and prospectuses and } \\
\text { Lexis Nexis Academic. }\end{array}$ \\
\hline $\begin{array}{l}\text { New product } \\
\text { introductions }\end{array}$ & Number of new products introduced in a given year. & Number & $\begin{array}{l}\text { Based on new product announcement data from LexisNexis Academic and Israeli } \\
\text { financial newspaper archives (Globes and The Marker) cross-checked with firms' } \\
\text { financial and own reports. }\end{array}$ \\
\hline Age & Firm age, in years. & Number & Based on D\&A and the IVC datasets. \\
\hline Development stage & Firm stage of development: seed, R\&D, initial sales, sales growth & Dummy & Based IVC dataset \\
\hline $\begin{array}{l}\text { Number of inventing } \\
\text { founders }\end{array}$ & Number of firm founders who have applied for patents in a given year. & Number & $\begin{array}{l}\text { NBER U.S. Patent Citations Data File complemented by USPTO website, } \\
\text { financial reports and prospectuses, DunsGuide Global, D\&A and IVC datasets. }\end{array}$ \\
\hline $\begin{array}{l}\text { Number of inventing firm } \\
\text { members }\end{array}$ & Number of firm members who have applied for patents in a given year. & Number & $\begin{array}{l}\text { NBER U.S. Patent Citations Data File complemented by USPTO website, } \\
\text { DunsGuide Global, D\&A and IVC datasets, financial reports and prospectuses and } \\
\text { Lexis Nexis Academic. }\end{array}$ \\
\hline $\begin{array}{l}\text { Number of external } \\
\text { stakeholder inventors }\end{array}$ & $\begin{array}{l}\text { Number of individuals in a firm's suppliers, customers, or partners who have } \\
\text { applied for patents in a given year. }\end{array}$ & Number & $\begin{array}{l}\text { NBER U.S. Patent Citations Data File complemented by USPTO website, } \\
\text { DunsGuide Global, D\&A and IVC datasets, financial reports and prospectuses and } \\
\text { Lexis Nexis Academic. }\end{array}$ \\
\hline $\begin{array}{l}\text { Number of founder } \\
\text { patents }\end{array}$ & Number of patents applied by a firm's founders in a given year. & Number & $\begin{array}{l}\text { NBER U.S. Patent Citations Data File complemented by USPTO website, } \\
\text { financial reports and prospectuses, DunsGuide Global, D\&A and IVC datasets. }\end{array}$ \\
\hline $\begin{array}{l}\text { Number of firm member } \\
\text { patents }\end{array}$ & Number of patents applied by a firm's firm members in a given year. & Number & $\begin{array}{l}\text { NBER U.S. Patent Citations Data File complemented by USPTO website, } \\
\text { DunsGuide Global, D\&A and IVC datasets, financial reports and prospectuses and } \\
\text { Lexis Nexis Academic. }\end{array}$ \\
\hline $\begin{array}{l}\text { Number of external } \\
\text { stakeholder patents }\end{array}$ & $\begin{array}{l}\text { Number of patents applied by individuals in a firm's suppliers, customers, or } \\
\text { partners in a given year. }\end{array}$ & Number & $\begin{array}{l}\text { NBER U.S. Patent Citations Data File complemented by USPTO website, } \\
\text { DunsGuide Global, D\&A and IVC datasets, financial reports and prospectuses and } \\
\text { Lexis Nexis Academic. }\end{array}$ \\
\hline
\end{tabular}

